CURRENT TOPICS ( 2)

\title{
金属表面による原子散乱過程と電荷・エネルギー交換
}

\author{
馬 越 健 次 \\ 大阪大学基礎工学部物性物理工学教室 $\bar{T} 560$ 大阪府豊中市待兼山町 1-1 \\ (1985 年 4 月 1 日 受理)
}

\section{Charge and Energy Exchange in Collision of Atoms with Metal Surfaces}

\author{
Kenji MAKOSHI
}

Department of Material Physics Faculty of Engineering Science

Osaka University Toyonaka, Osaka 560, Japan

(Received April 1, 1985)

\begin{abstract}
Recent theory of the resonant electron transfer in atom scattering from a metal surface is reviewed with emphasis of the limiting formulae which give simple physical interpretations. The atom is assumed to follow a given classical trajectory. The electronic system is treated quantummechanically within the wide band approximation for the metal conduction band, since the motion of the atom is assumed to be slow. For the charge exchange problem, the electron correlation is incorporated into the theory within the Hartree-Fock approximation. Only low-lying electron-hole pair excitations are accounted for as the energy dissipation channel.
\end{abstract}

\section{1. はじめに}

表題にあるような現象，特に電荷移動については，か なり盛んに実験が行なわれる様になり，理論的にも研究 が進み，一定の仮定を満足するような場合には，半定量 的に実験を説明できる様になってきた ${ }^{1-5)}$ 。従って，て れらの問題についての反省む込めて，概観するてとに意 味がある時期に来ていると思われる．乙れによっててれ からの問題点が少しであ明かになれば幸いである。

金属表面による粒子（原子，イオンあるいは分子でも よいが以下では粓子と呼ぶことにする）の散乱を考える が，金属に一番特有の性質は Fermi 面の存在である。 エネルギー移動には, この Fermi 面の存在が顕著な効

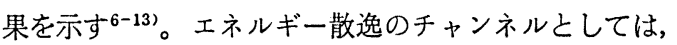
格子振動や, 分子の場合には分子内振動, 回転励起等色 々考え得るが，乙こでは扱わないととにする．また電荷 移動の問題には，笔子間相互作用のない場合，いわゆる Fermi 面効果はないととが示されている(14) が，問題に する原子上の電子準位が Fermi 準位 $\left(\varepsilon_{F}\right)$ に近い場合, これは電子移動の位相空間が広いととを意味し，興味あ る現象が期待できる。とこでは，いわゆる Resonant
Tunneling (RT) 過程に話を限るととにする。

金属による原子の散乱に現われるエネルギーとして は，（i）粒子の入射エネルギー，（ii）金属の表面 plasmon の励起エネルギー，（iii）金属の伝導帯の巾，（iv） Fermi 面からはかった粓子上の電子準位, (V)電子一正 孔励起のエネルギー, 等であるが, ここではまず, 粒子 の入射エネルギーが充分小さく表面 plasmon は真の励 起とはならず, 粒子に働くポテンシャルを断熱的にスク リーンするとして取り扱えるとする。ての範囲で解きた い問題は, 次の Hamiltonian で表わされる粒子の散乱 問題である。

$$
H=\frac{P^{2}}{2 M}+V_{a d}(\boldsymbol{R})+H_{c}(\boldsymbol{R})
$$

ここで, 第一項は粒子の運動エネルギー, 第二項は断熱 ポテンシャル，第三項は電子系の Hamiltonian で粒子 の座標に依存する。

この Hamiltonian が散乱問題として解ければすべて の情報が得られるわけであるが，それは今のとてろ至難 の業のようである。一番の問題は粒子の運動量演算子之 粒子に働くポテンシャル，特に第三項とが可換でないと とにある。そこで，粒子の運動を古典的に考え，エネル 
ギーの移動は始めから小さいとして外から与えてしまお う(古典軌道近似)。乙の近似の正当性の検討も始まっ ている ${ }^{15}$ が未解決である。こうすると今度は粒子の運動 を与えてしまったために電子系の Hamiltonian がその 座標（ててでは簡単のために表面に垂直方向のみ考える ことにする）を通して，時間に顕わに依存することにな る。その様な時，基本的にどの様な事がおこるかを見る ためによく用いられる模型として，時間に依存する Newns-Andeson (NA) 模型16,17)がある。乙れは

$$
\begin{aligned}
H_{A}(t)= & \sum_{\boldsymbol{k}} \varepsilon_{\boldsymbol{k}} c_{\boldsymbol{k} \sigma}{ }^{+} c_{\boldsymbol{k} \sigma}+\sum_{\sigma} \varepsilon_{a}(t) c_{a \sigma}{ }^{+} c_{a \sigma} \\
& +\sum_{\boldsymbol{k}} V_{\boldsymbol{k}}(t)\left(c_{\boldsymbol{k} \sigma}{ }^{+} c_{a \sigma}+c_{a \sigma}{ }^{+} c_{\boldsymbol{k} \sigma}\right) \\
& +U(t) c_{a \uparrow}{ }^{+} c_{a \uparrow} c_{a \downarrow}{ }^{+} c_{a \downarrow}
\end{aligned}
$$

で与えられる。乙てで， $c_{k \sigma}$ と $c_{a \sigma}$ は，各々スピン $\sigma$ を あつ金属中の非摄動電子系の状態 $|\boldsymbol{k}\rangle$ (エネルギー $\varepsilon_{\boldsymbol{k}}$ ) をあつ電子及び原子上の軌道 $|a\rangle\left(\varepsilon_{a}(t)\right)$ にある電子の

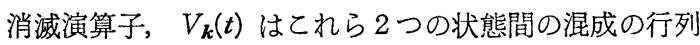
要素, $U(t)$ は原子上の同一軌道に 2 個電子がはいったと きの電子間の Coulomb 反発のエネルギーである。粒子 の座標に依存する項はその運動を通して時間 $t$ に依存す る。例えば表面からかなりはなれた場所 $z$ で原子のイオ ン化準位 $\varepsilon_{a}(z)$ は鏡像力を考慮すれば

$$
\varepsilon_{a}(z) \simeq \varepsilon_{a}(\infty)+\frac{1}{4 z}
$$

Coulomb 相互作用（これはイオン化準位と電子親和力 との差で与えられる) は

$$
U(z) \simeq U(\infty)-\frac{1}{2 z}
$$

軌道混成は，金属からの電子の波動関数のしみだしを反 映して

$$
V(z) \simeq V(0) \mathrm{e}^{-\alpha z}
$$

の様な振舞いをすると考えられる。(ここでは原子単位 系を用いる。)

このNA模型は，時間に依存しない場合には厳密解が 得られている ${ }^{18,19)}$ が，それを時間に依存する場合に応用 することは難しく，でく特殊な状況において適用されて いるにすぎない20)。後でこの模型に Hartree-Fock(HF) 近似を行なった結果を紹介するが，暫くは $U=0$ として 議論を進める。例えば，イオン化準位が $\varepsilon_{F}$ の近くにあ りUが充分大きくて電子親和準位の存在が問題にならな いような場合や，逆にイオン化準位は充分深く，常に電 子が一つ詰まっていて $\varepsilon_{F}$ 近傍に電子親和準位がくる場 合の様に, ぞちらか一方のみを考えればよさそうな場合 ああるので，適当な状況を考えれば必ずしあ現実とかけ はなれた模型ということにはならない。従って，てれか ら考える Hamiltonian は

$$
H(t)=\sum_{k} \varepsilon_{k} c_{k}{ }^{+} c_{k}+\varepsilon_{a}(t) c_{a}{ }^{+} c_{a}
$$

$$
+\sum_{\boldsymbol{k}} V_{\boldsymbol{k}}(t)\left(c_{\boldsymbol{k}}{ }^{+} c_{a}+c_{a}{ }^{+} c_{k}\right)
$$

である（一体問題の場合スピンは分離してしまうから, スピンのない Fermi 粒子とする)。この Hamiltonian を基にして計算したい量 ${ }^{10.211}$ は

$$
\begin{aligned}
& n(t)=\left\langle t\left|\hat{n}_{a}(t)\right| t\right\rangle \\
& P(\varepsilon)=\left\langle\infty\left|\delta\left(\varepsilon+E_{0}-\hat{H}(\infty)\right)\right| \infty\right\rangle
\end{aligned}
$$

で与えられる。ここで $\hat{n}_{a}(t)=c_{a}{ }^{+}(t) c_{a}(t)$ は粒子上の準位 の占有数の Heisenberg 演算子, $|t\rangle$ は時刻 $t$ におけ る電子系の状態, $E_{0}$ は初期状態のエネルギー, $\hat{H}(\infty)$ は やはり Heisenberg 表示での $t=\infty$ での Hamiltonian を表わす。(8)式の $p(\varepsilon)$ の意味は, 見て明らかな様に, 電子系の終状態が初期の状態より $と$ だけ高いエネルギー を持つ確率を与える。この分だけ粒子が電子系にエネル ギーを与えた（自分は失った）之考えるわけである。

解析的にある程度まで扱えるのは，いわゆる金属バン ド巾無限大の極限 $(\mathrm{WBA})^{14)}$ のみで，これは粓子の垂直 速度 $V_{\perp}$ が遅く, 例えば, 格子間距離を進むに要する時 間が，金属のバンド巾Dの逆数時間より充分長い場合に 成り立つ近似になる。以下ではこのような場合を考察す る。

一般の時間依存性を Hamiltonian が有する時は, 断 熱定理は単純には適用できず, 本質的に非平衡の問題を 扱うことになる。例えば, 先に金属側の準位を連続にと ってしまえば，その後いくら粒子の運動を遅くしてあ， 断熱散乱因子が 1 にならない事が指摘されている ${ }^{6)}$ 。乙 の様な非平衡系の統計力学を扱う方法として Keldysh ${ }^{22)}$ のグリーン関数法（KG 関数之略記）がある。表面の問 題に於ける粒子の電荷を扱うために, この方法を導入し たのは Blandin, Nourtier \& Hone ${ }^{14)}$ である。より古 典的なグリーン関数法 ${ }^{23)}$ は, 固体物理の諸問題を解くに あたって種々の貢献をなしてきた。それと同程度の貢献 を $\mathrm{KG}$ 関数あ担う可能性はあるが，ここではその詳細に はあまりふれず，結果だけを引用するととにする。

電荷移動については, NA 模型を扱い, HF 近似によ る取り扱い24-26) まで紹介し， $p(\varepsilon)$ に関してはあう少し 一般的な散乱ポテンシャルについての結果 ${ }^{11,12)}$ を示し, それから簡単な場合にどの様な結果が得られるかを紹介 する。

\section{2. 電 荷 移 動}

電子系の波動関数 $|t\rangle$ は

$$
\mathrm{i} \frac{\partial}{\partial t}|t>=H(t)| t>
$$

に従って発展する。 $t=-\infty$ での状態がわかれば, $|t\rangle$ は

$$
|t>=U(t,-\infty)|-\infty>
$$




$$
=\mathrm{T} \exp \left[-\mathrm{i} \int_{-\infty}^{t} H\left(t^{\prime}\right) \mathrm{d} t^{\prime}\right] \mid-\infty>
$$

と形式的に書くととができる。ここでTは時刻の大きい 方を左にもってくる時間秩序演算子であり，異なる時刻 における Hamiltonian が可換でないために必要であ る。

Blandin et al. ${ }^{14)}$ の論文で示された重要な結論の $1 つ$ は電荷の問題にはいわゆる Fermi 面効果は, 直接反映 されないというととであろう。このため, 電荷移動の問 題は比較的取り扱いやすい問題となっている。さらには 散乱された粒子の電荷については実験むかなり進められ ているので, 種々の角度から研究が進んでいる。

軌道混成の行列要素が

$$
V_{k}(t)=V_{k} u(t)
$$

の様に時間依存性の部分が因子化される場合には問題が 解けて

$$
\begin{aligned}
& n(\infty)= n(-\infty) \exp \left[-2 \int_{-\infty}^{\infty} \Delta\left(t^{\prime}\right) \mathrm{d} t^{\prime}\right] \\
&+\sum_{\boldsymbol{k}} f_{\boldsymbol{k}+\boldsymbol{Q}}(T)\left|V_{\boldsymbol{k}}\right|^{2} \\
&\left|\int_{-\infty}^{\infty} u(t) \mathrm{e}^{-\mathrm{i} \varepsilon_{\boldsymbol{k}} t} g(\infty, t) \mathrm{d} t\right|^{2} \\
& g\left(t, t^{\prime}\right)= \exp \left[\int_{t^{\prime}}^{t}\left\{\mathrm{i} \varepsilon_{a}(\tau)+\Delta(\tau)\right\} \mathrm{d} \tau\right] \\
& \Delta(t)=\pi \sum_{\boldsymbol{k}}\left|V_{\boldsymbol{k}}\right|^{2} \delta\left(\omega-\varepsilon_{\boldsymbol{k}}\right) u(t)^{2}
\end{aligned}
$$

が得られる。ここで WBA を考えるため(14)式中で， には $\omega$ 一依存性がないとした。(12) 式中に現われる $f_{\boldsymbol{k}+\boldsymbol{Q}}(T)$ は運動量 $\boldsymbol{k}+\boldsymbol{Q}$ をむつ電子の Fermi 分布関数 で, 初期状態において, (散乱問題を考え, $V_{\boldsymbol{k}}(-\infty)=0$ とする) 金属の電子系が熱平衝にあったととを意味す る。粒子の表面に平行な速度 $\boldsymbol{v}_{\|}$はかなり速い場合む考 えに入れることにし，粒子についた座標系から見れば金 属の Fermi 面が $-\boldsymbol{Q}=\boldsymbol{v}_{\|}$だけずれて見えることを考 虑してある。詳しい議論については文献（31）を御覧頂 きたい。とれから，ての式の特別な場合についてどの様 なととがいえるかを見ていくことにする。

(a) 記憶の項

先ず (12) 式の第一項について考える。 $\mid a>$ 準位に電 子が存在すると, その準位は金属の伝導帯と混成がある ので有限の巾 $2 \Delta$ をす。従って, 金属側からの電子の 流入を考えなければ単位時間に $2 \Delta(t)$ で減衰してしま う。この Rate 方程式を立てて積分すれば，乙の項がえ られる。

例えば, 粒子が等速運動をし, 表面からの距離 $z(t)$ が

$$
z(t)=v_{\perp}|t|
$$

で与えられるとし， $\Delta(z)=\Delta(0) \exp (-\alpha z)$ とすると,

$$
n(\infty)=n(-\infty) \exp \left[-4 \Delta(0) / \alpha v_{\perp}\right]
$$

が得られる。 $\Delta(0)$ が $\alpha v_{\perp}$ に比べて大きく，ての記憶効 果は無視できる場合が多い。その時は，(12)式第二項の 計算も表面から外に向かう経路の分だけやればよい21。 以下 $((\mathrm{b}),(\mathrm{c}))$ ではその様な場合を取り扱う。

(b) $\varepsilon_{a}$ が Fermi 準位をよぎる場合

粒子が表面近傍にある時， $\varepsilon_{a}$ は $\varepsilon_{F}$ より下にあり，電 子が占有していたとし，表面から遠のくに従って $\varepsilon_{a}$ が 上に上がり， $z=z_{c}$ で $\varepsilon_{F}$ を通過するとしよう：

$$
\varepsilon_{a}(z)=C\left(z-z_{c}\right)
$$

あし

$$
C / v_{\perp}>\alpha v_{\perp}
$$

ならば

$$
n(\infty)=\exp \left[-2 \Delta\left(z_{c}\right) / \alpha v_{\perp}\right]
$$

とかなり良い近似で表わされることが示されてい る $^{21,27-29)}$ 。乙の式は $\varepsilon_{a}$ が $\varepsilon_{F}$ をよざる時のその準位の 巾で電荷状態が最終的にきまることを意味している。 $\varepsilon_{a}$ が $\varepsilon_{F}$ より下にある時はほぼ電子はその準位にとどまっ ているが，それより上に行けば，金属中の空の状態への 電子移動が可能になるととにより, その時点から $\Delta(\boldsymbol{z})$ に従って減衰すると見るととができる。そのための条件 が不等式 (18)である。

(c) $\varepsilon_{a}$ が一定の場合

平行速度の効果む含めて適当な近似を行なえば4)

$$
\begin{aligned}
n(\infty)= & \frac{1}{2 \alpha v_{\perp}} \int_{-\infty}^{\infty} \frac{d \varepsilon}{\cosh \left[\pi\left(\varepsilon-\varepsilon_{a}\right) / 2 \alpha v_{\perp}\right]} \\
& \cdot \frac{\left\langle f_{\boldsymbol{k}+\boldsymbol{Q}}\left|v_{\boldsymbol{k}}\right|^{2}\right\rangle_{\varepsilon}}{\left\langle\left|v_{\boldsymbol{k}}\right|^{2}\right\rangle_{\varepsilon}}
\end{aligned}
$$

が得られる。く $\rangle_{\varepsilon}$ は $\varepsilon_{\boldsymbol{k}}=\varepsilon$ の等エネルギー面での平均 を意味する。

$$
\begin{aligned}
& \text { (c一i ） } \boldsymbol{Q} \text { が小さい場合 } \\
& \boldsymbol{Q}=0 \text { の場合積分が実施できて } \\
&
\end{aligned}
$$

$$
n(\infty)=\frac{2}{\pi} \tan ^{-1} e^{-\pi\left(\varepsilon_{a}-\varepsilon_{F}\right) / 2 \alpha v_{\perp}}
$$

となる。 $\varepsilon_{a}$ が丁度 $2 \alpha v_{\perp} / \pi$ の巾をむって広がり， $\varepsilon_{F}$ よ り下の部分に電子をつめた形をしている。これは粒子の 運動によるエネルギーの不確定性を如実に反映した非断 熱効果であるが，式からあ解る通り，粒子の速度 $v_{\perp}$ を 小さくしていった極限は断熱極限になる。電荷の問題に は Fermi 面効果が表だって現われないととの反映でも ある。ここに少し平行速度の効果を加えると，(20)式の 被積分関数の第 2 項により Fermi 面が少しずれ， $\varepsilon_{a}$ の

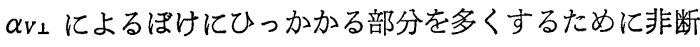
熱効果が増巾されるだけである4)。

(c一ii) Doppler 効果

逆に平行速度の効果が重要になるのは

$$
k_{F} v_{11}>\varepsilon_{a}-\varepsilon_{F}
$$


が満たされるほど v川が大きくなる場合である4,31,32)。 $V_{\perp}$ が充分小さければ，(21) 式の皘分で, $k^{2} / 2=\varepsilon_{a}$ を満 足する球とずらした Fermi 球 $|\boldsymbol{k}+\boldsymbol{Q}|^{2}=k_{F}^{2}$ との交点 がどの程度あるかが問題になる場合がある。その様な場 合 (20)式被積分関数の第一項をデルタ関数でおきかえて しまえば $n(\infty)$ は

$$
n(\infty)=\frac{\left\langle f_{k+Q}\left|V_{k}\right|^{2}\right\rangle_{\varepsilon=\varepsilon_{a}}}{\left\langle\left|V_{k}\right|^{2}\right\rangle_{\varepsilon=\varepsilon_{a}}}
$$

となり,ずらした Fermi 球内 $k^{2}=\partial \varepsilon_{a}$ のととろの行列 要素 $V_{\boldsymbol{k}}$ の大きさによって電荷状態がきまる (Fig. 1)。 च川が非常に大きくなれば式 (23) は小さくなっていく。 すなわち $\varepsilon_{a}$ が Fermi 準位より上にあった場合, 非断 熱効果を減少させる方向に働く。Fig.2亿もっ之精密な 計算をした結果と実験結果（H の Cs/W (110) による散 乱 ${ }^{32,33)}$ との比較を示してある。乙れをみてあわかる通 り，吸着 Cs が少ないほど，電子のトンネルに笴与する 実効的な Fermi 球は小さいと考えられるとすれば, ข の効果は大きくなるととになる。また予期した通り、び は非断熱効果を減少させる方向に働いている。計算は, ジェリウムと水素についての距離に依存した電子状態の 計算を用いているが，理論の簡単さに比して実験との一 致は，驚く程良い。

(d) 多体効果之 $\mathrm{HF}$ 近似

今まで 1 体問題 $(U=0)$ を扱ってきたが，実際には $U$ は決して0ではない。ての多体問題を扱う第一歩とし て，HF 近似による取り扱(24-26)を紹介する。

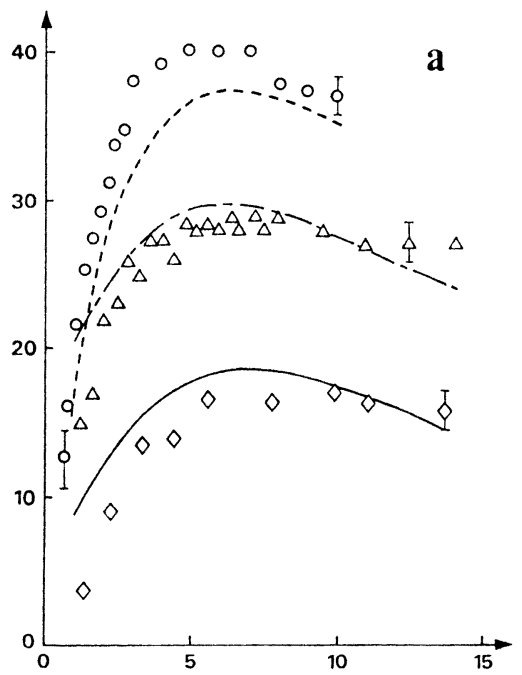

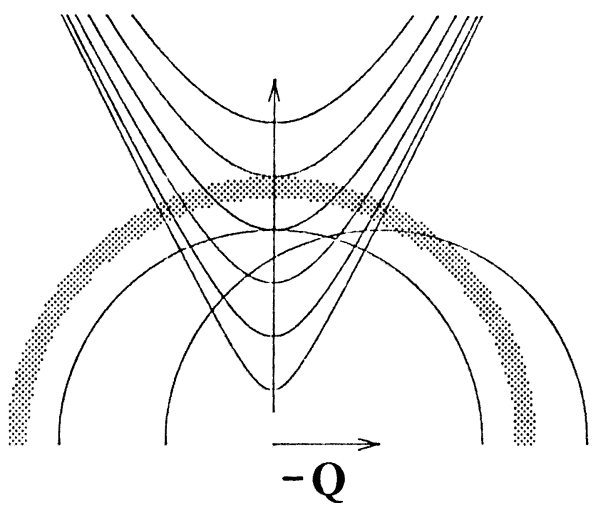

Fig. 1 A sketch of the contour of $\left|V_{k}\right|^{2}$ and the Fermi surfaces $k^{2}=k_{F}^{2}$ and $|\boldsymbol{k}+\boldsymbol{Q}|^{2}=k_{F}^{2}$. The vertical arrow shows the direction of increasing $\left|V_{k}\right|^{2}$ and the horizontal one $-\boldsymbol{Q}$. The dotted ring expresses the $k^{2}=2 \varepsilon_{a}$ with a certain width.

$\mathrm{HF}$ 近似は一体近似であるから，Q=0 として (12)式 が援用できる。ただし，今度はスピンも顕わに書いてお くことが必要で(13)式に現われる $\varepsilon_{a}(\tau)$ は

$$
\varepsilon_{a \sigma}(\tau)=\varepsilon_{0 \sigma}(\tau)+U\left\langle\tau\left|\hat{n}_{-\sigma}(\tau)\right| \tau\right\rangle
$$

$(\sigma= \pm)$ 之書きかえなりればならない。その場合 (12) 式 （にスピンの足 $\sigma$ をつけたもの）は $n_{\sigma}(t)$ に対する連立 非線型皘分方程式となるので，適当な初期条件の下で数 值解を求め杖ばならない。計算は種々の時間依存性につ いて行なわれているが24 26)，ここでは最む簡単な場合に

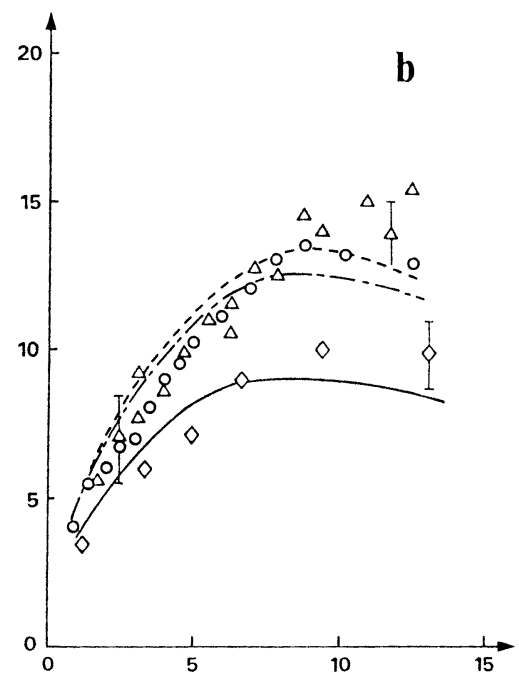

Fig. 2 Comparison between theory (lines) and experiments $(\mathrm{O}, \Delta$ and $\diamond)$ for the $\mathrm{H}^{-}$ fraction (\%) in the scattered particles as a function of the normal velocity (in $10^{4}$ $\mathrm{m} / \mathrm{sec}$ ) : (a) $\mathrm{Cs}_{\mathrm{s}} / \mathrm{W}(110)$ at the work function minimum, and (b) thick Cs layer. The energies of incident particles are $400 \mathrm{eV}(\mathrm{O}$ and ---$), 1000 \mathrm{eV}(\triangle$ and --$)$ and $2000 \mathrm{eV}(\diamond$ and - ). 
ついての結果 ${ }^{24)}$ のみ紹介するととにする。それは, 粒子 が等速度 $v_{\perp}$ で運動するとし，表面との相互作用は表面 から $L$ だけの距離に限られ，しかも $\varepsilon_{a}, U$ はそので一 定であるとしよう。すると粒子が表面と相互作用するの は $t=0$ から $2 L / v_{\perp}$ までで, その後電子のやりとりはし なくなるから，出てくる粒子の電荷は $t=2 L / v_{\perp}$ のそれ で与えられることになる(Fig. 3)。従って $u(t)=\theta(t)$ (階段関数) として，時間を追って $n_{\sigma}(t)$ を見て行けばよ いととになる。Fig.4亿計算結果を示す。計算は簡単の ために $\varepsilon_{a}=-U / 2$ (対称 Anderson 模型と呼ばれる) と

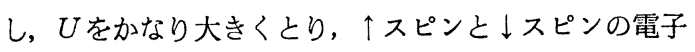
の占有数に (平衡状態で) 差の生ずる条件（磁性の起る 条件）としてある。初期条件は，十のイオンが入射する 場合で, 粒子上の電子数 0 にとってある。乙の場合, ス ピンが分極した状態に最後に到達するためにはスピン空 間に対称性を破る何らかの原因が必要なため, 粒子上の 準位に仮想的な磁場による Zeeman 分離を仮定してあ る。図から解ることは, 電荷移動が 3 段階（仮想磁場が 大きい時にはあまり判然としないが）に分かれているて とである。第一は電荷がその平衡值 1 に近づく段階でそ

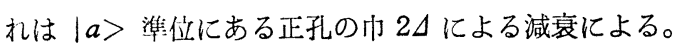
しかし，電子が $|a\rangle$ に流れ込めば，電子間相互作用の ため有効準位が㠇くなり，流入がなくなってくるが，そ の前に少し行きすぎる傾向がある。

次に，スピン分極が始まるが，乙れは指数関数的に増 大する。興味あることは, 乙の指数が $(V \overline{U / \pi \Delta}-1) t$ と なることで, 確かに $U / \pi \Delta>1$ は平衡でスピン分極の現 われる条件であり，その時にスピン分極が成長している

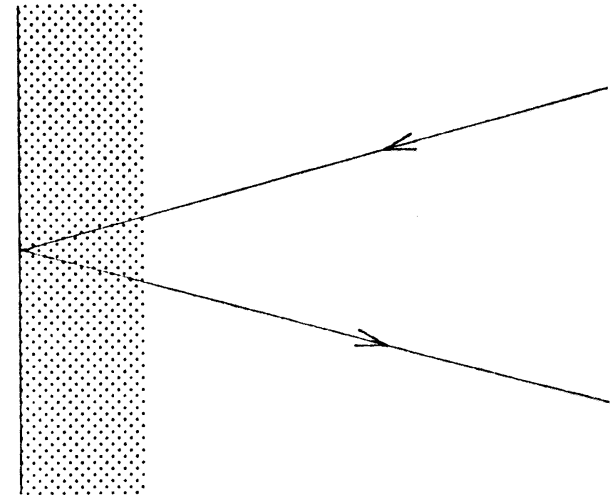

Fig. 3 A sketch of the model in the text. The shaded area is the region where the particle interacts with the surface.

ことを示しているが, 実際に指数に現われるのがUに関 して非解析的な $V \bar{U}$ であるてとである。この部分は, 仮想磁場によるZeeman 分離の大きさに比例しているの で, 実際の問題の場合どうとるか問題はのこる。おそら く, スピン系について回転不変な取り扱いをした時に は，自然にその様な量は決まると思われる（例えば，ス ピンの摇らぎ等で）が，てのV $\bar{U}$ 依存性はもしかした ら一般的なあのかす知れない。

最後の段階はスピン分極すほほ平衡值に近づき，その まわりで摇らいでいる状態を示している。その周期は $\left|\varepsilon_{a}-\varepsilon_{F}\right|$ が比較的大きい場合 $2 \pi /\left|\varepsilon_{a}-\varepsilon_{F}\right|$ で $\mid a>$ 準位 と Fermi 準位との間の電子のやり取りが主原因であり, バンド巾の効果ではない。

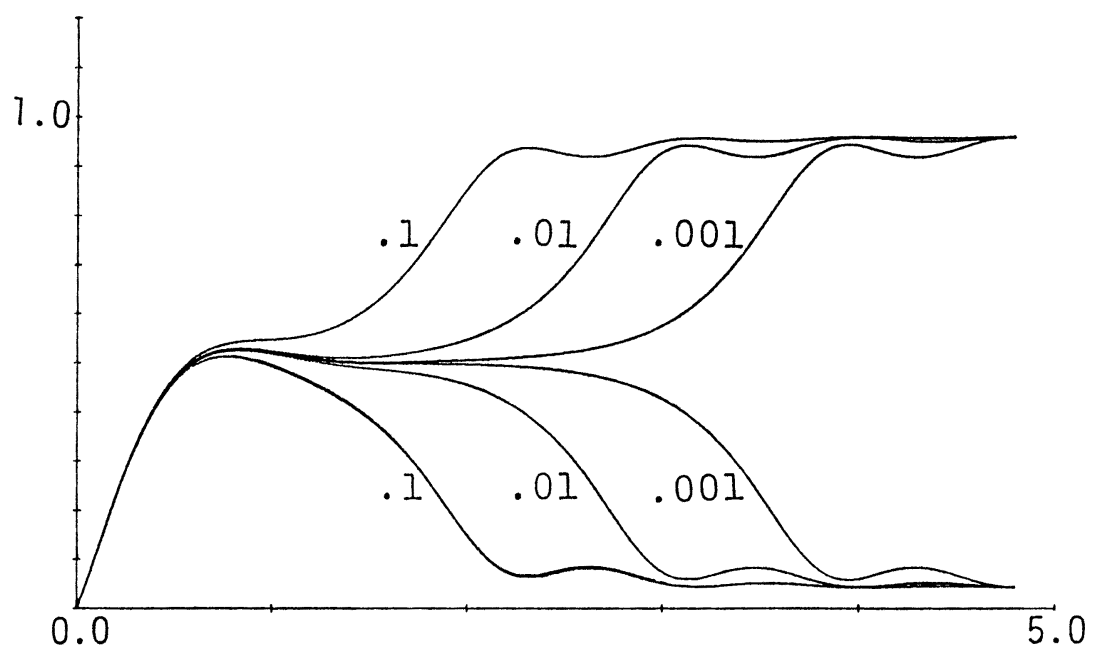

Fig. 4 Numerical results of the Hartree-Fock calculations: upper curves are for majority spin electron and lower for minority. The numbers in the figure show a half of the Zeeman splitting by the ficticious magnetic field. 


\section{3. エネルギー散逸}

エネルギーの分布は電荷移動よりあ多くの情報を必要 とし, Fermi 面効果があるに効いてくるので, 話が少し 複雑になる ${ }^{6 \sim 12)}$ 。先ず，（8) 式を值接扱うよりあ, その Fourier 変換 :

$$
\begin{aligned}
\Pi(\tau) & =\int_{-\infty}^{\infty} P(\varepsilon) \mathrm{e}^{-\mathrm{i} \varepsilon \tau} \mathrm{d} \varepsilon \\
& =\left\langle\infty\left|\mathrm{e}^{-\left[H(\infty)-E_{0}\right] \tau}\right| \infty\right\rangle
\end{aligned}
$$

の方が扱い易い。

この $\Pi(\tau)$ （散逸関数之呼ぶ）を時間発展演算子 ((10) 式参照）を導入して書くと

$$
\begin{aligned}
\Pi(\tau)= & \lim _{\mathscr{F} \rightarrow \infty}\langle-\infty| U^{+}(\mathscr{F},-\infty) \\
& U(\mathscr{F}+\tau,-\infty) \mathrm{e}^{\mathrm{i} H_{0} \tau|-\infty\rangle}
\end{aligned}
$$

となる。ただし $\mid-\infty>$ は $H_{0}$ の 1 つ固有状態にあ るとし，そのエネルギー固有值を $E_{0}$ であるとした：

$$
H_{0}\left|-\infty>=E_{0}\right|-\infty>
$$

ここで $U^{+}$とUとで時間てだけずれていることが重要 である。乙のととは，乙の種の古典的な問題としてよく 知られたX線の吸収端の問題 ${ }^{34)}$ を振り返ってみればよく 解る。この問題は時間に依存する Hamiltonian の特殊 な場合として理解できる。内殼の電子がX線を吸収する と, その内殼に正孔をつくる。この正孔は伝導電子に散 乱ポテンシャル $V$ を作用させる。従って時間依存性は階 段関数で表わされる。その場合 $\Pi(\tau)$ は $V$ が作用し始め てからて後の電子状態と作用前の基底状態との重なり積 分になる。伝導電子系は, 散乱ポテンシャルが作用して いる時の基底状態へ漸近的に緩和していくが，その長時 間漸近形が, Fermi 面の効果を反映し, 特異な振る舞い をする。この物理は Anderson の直交定理 ${ }^{36)}$ にり理解 されている。その原因はもちろん Fermi 面の存在で, それにより, 電子一正孔励起が励起エネルギー0から連 続的に存在するととによる。表面による散乱問題の様 に, 一般的な時閫依存性がある場合も当然この Fermi 面効果は現われる。

散逸関数は, 時間 $\tau$ のずれのため, 従来の $\mathrm{KG}$ 関数 を用いて書くことはできないが，少し抆張したグリーン 関数を導入すれば書き表すことができる11,12)。それには 熱力学関数を温度グリーン関数を用いて表わす道筋 ${ }^{23)}$ たどってやればよい。詳細を省いて結果のみ示すと

$$
\begin{aligned}
\Pi(\tau)= & \exp [C(\tau)] \\
C(\tau)= & -\int_{0}^{1} \mathrm{~d} \lambda \int_{-\infty}^{\infty} \mathrm{d} t \sum_{\boldsymbol{k}, \boldsymbol{k}^{\prime}}\left[V_{\boldsymbol{k} \boldsymbol{k}^{\prime}}(t+\tau)\right. \\
& G_{\boldsymbol{k}^{\prime} \boldsymbol{k}^{++}}\left(t, \boldsymbol{t}^{+} ; \lambda\right)-V_{\boldsymbol{k} \boldsymbol{k}^{\prime}}(t) \\
& \left.G_{\boldsymbol{k}^{\prime} \boldsymbol{k}^{--}}\left(t^{+}, t ; \lambda\right)\right]
\end{aligned}
$$

数で, グリーン関数の計算の際, 散乱ポテンシャル $V_{\boldsymbol{k} \boldsymbol{k}^{\prime}}$ を $\lambda V_{\boldsymbol{k} \boldsymbol{k}^{\prime}}$ でおきかえる。初期状態は $T=0$ 即ち金属中の 電子は $\varepsilon_{F}$ まで完全につまっているとする。WBA を採 用し, Nozieres \& de Dominicis ${ }^{34)}$ によりX 線吸収端 異常について正しい結果を与える事が示された Muskh. elishvili の方法 ${ }^{35)}$ を援用すると， $C(\tau)$ のうち, 非断熱效 果を表わす項 $C_{\mathrm{NA}}(\tau)$ は, Fermi 面のところの $S$-行列 を用いて無限級数の形に書き表す事ができる゙11。Fermi 面の存在は, 新しく定義したグリーン関数の積分核に琴 われる長時間の振る舞い $\left(t-t^{\prime} \pm \mathrm{i} 0\right)^{-1}$ に反映される。乙 の項がグリーン関数を展開した時に各次数の分だけ現わ れるというのが，乙の問題におけるいわゆる Fermi 面 効果であると言ってもよい。もし $\tau=0$ ならば, S-行列 の unitarity のため級数の各項は 0 になってしまう。従 って, 従来の $\mathrm{KG}$ 関数 $(\tau=0$ として得られる) には, この様な級数は現われない。電荷の計算に必要なのは従 来の KG 関数であるから, 電荷には Fermi 面効果は現 われない, 言いかえれば, 電荷は特異な長時間の漸近形 をあたないととが解る。

一般的なポテンシャルに対する形式解はまだ整理され た形にはなっていないが, NA 模型の様に $S$-行列が唯 一つの位相のずれ $\delta(t)$ でかける場合は， $S$ はスカラーと みなせるからコンパクトな表式が求まる。

$$
C_{\mathrm{NA}}(\tau)=\frac{1}{\pi^{2}} \int_{0}^{\infty} \omega\left(\mathrm{e}^{-\mathrm{i} \omega \tau}-1\right)|\eta(\omega)|^{2} \mathrm{~d} \omega
$$

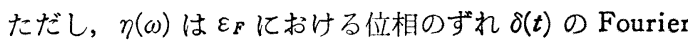
変換である：

$$
\eta(\omega)=\int_{-\infty}^{\infty} \delta(t) \mathrm{e}^{\mathrm{i} \omega t} \mathrm{~d} t
$$

ここで重要なことは， $C_{\mathrm{NA}}(\tau)$ が位相のずれの Fermi 面 における值で決まってしまうことである。

平均のエネルギー損失は $p(\varepsilon)$ の第一モーメントで与 えられるから

$$
\Delta \varepsilon=\mathrm{i} \dot{C}_{\mathrm{NA}}(0)=-\int_{-\infty}^{\infty} \frac{\mathrm{d} t}{4 \pi}\{\dot{\delta}(t)\}^{2}
$$

で与えられるが, これは摩擦係数 ${ }^{37,38)}$ から計算したエネ ルギー損失に他ならない。

散乱の場合は, $t=-\infty$ と $t=\infty$ での Hamiltonian が同一であるから, 弾性散乱因子 $p_{0}$ が存在する。それ は, $\tau \rightarrow \infty$ をとって

$$
P_{0}=\exp \left[-\frac{1}{\pi^{2}} \int_{0}^{\infty} \omega|\eta(\omega)|^{2} \mathrm{~d} \omega\right]
$$

これからあわかることは, あし，入射粒子と散乱粒子と で対称な経路を考え, 唯一の時間の尺度 $T$ で記述される $(\delta(t)=\delta(t / T))$ と仮定すると $P_{0}$ は $T$ によらない。これ が文献 6) で指摘されたととであるが，Tを大きくして 
行けば平均のエネルギー損失は０になるからそれまで合 わせれば断熱極限に行くと思ってよいと思われる。

\section{4. おわりに}

以上, RT による電子移動を伴う表面散乱過程の非断 熱効果を粒子速度が遅い場合にみてきたが，理論側から みれば，まだまだ問題は山積している。てれらを解决し て行てうという試みあ少しづつ出てきてはいるが，それ らには触れなかった。例えば，バンド巾有限の効果がど の様にあらわれるか，1体問題の範囲で，適当な模型に より数值計算を行なって見ようとする試み ${ }^{39)}$ ，静的な Anderson 模型の㛜密解の知識を援用しようとする試 み ${ }^{20)}$, 等なされている。さらには, 古典軌道近似からの ずれをみることにより，どの様な場合にそれが成立する かみきわめようとする試み15)等もあるが，ここでは触れ なかった。さらに，最近は実験が進み入射粒子あるいは 散乱粒子として，励起状態にある原子をプローブとして

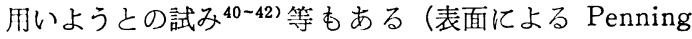
イオン化等に代表される)。例えば $\mathrm{He}$ の (1s 2s) 状態は イオン化準位が，仕事関数の比較的大きい金属の場合そ の Fermi 準位あたりに来るので, Resonant Tunneling の研究にも役立つと思われる ${ }^{41)}$ 。特にUの問題は, 必ず 何らかの解決が必要ではあるが，何か理論の飛躍的な進 歩が必要かも知れない。それは，表面に近づいた時に， その距離における平衡状態での有効䊀子準位は, 非磁気 的になっていても，散乱されて表面から遠のくに従って 必ずどてかで磁性状態に移るはずである。乙の場合，い わゆる近藤効果 ${ }^{43}$ はどういう寄与を電荷移動におよぼす のであろうか。

最後に，ここに書いた大部分はDr. D.M. Newns (lmperial College, London), Dr. R. Brako (Institute Rudjer Boškovic, Zagreb), Dr. J. N. M. van Wunnik, (FOM Institute, Amsterdam), 吉森昭夫教授, 河合伸 氏（阪大基礎工）との議論によりできたものである。乙 れらの諸氏に感謝の意を表します。また横文字諸氏に出 会う機会を与えてもらった英国 SERC 及び Imperial College, Institut Laue Langevin に感謝します。

\section{文献}

1) B. I. Lundqvist, O. Gunnarsson, H. Hjelmberg and J. K. N $\phi$ rskov : Surf. Sci. 89, 196 (1979).

2) G. Blaise and A. Nourtier : Surf. Sci. 90, 495 (1979).

3) R. Brako and D. M. Newns: Vacuum 32, 39 (1982).

4) D. M. Newns, K. Makoshi, R. Brako J. N. M. van Wunnik: Physica Scripta T6, 5 (1983).

5) R. Brako, K. Makoshi and D. M. Newns: Proc
XI IVC and V ICSS, Madrid (1983), ed. J. L. de Segovia (Imprenta Moderna, Madrid, 1983).

6) E. Müller-Hartmann, T. V. Ramakrishnan and G. Toulouse : Solid State Commun. 9, 99 (1971) ; Phys. Rev. B3, 1102 (1971).

7) J. K. N $\phi$ rskov and B. I. Lundqvist : Surf. Sci. 89, 251 (1979).

8) G. P. Brivio and T. B. Grimley: Surf. Sci. 89 226 (1979).

9) K. Schönhammer and O. Gunnarsson: Phys. Rev. B22, 1629 (1980).

10) R. Brako and D. M. Newns : Solid State Commun. 33, 713 (1980): J. Phys C: Solid State Phys. 14, 3065 (1981).

11) K. Makoshi : J. Phys. C : Solid State Phys. 16, 3617 (1983).

12) K. Makoshi : Dynamical Processes and Ordering on Solid Surfaces (Proc. VII Taniguchi Symposium), ed. A. Yoshimori and M. Tsukada (Springer-Verlag, Berlin, 1985),

13) K. Schönhammer and O. Gunnarsson: Dynamical Processes and Ordering on Solid Surfaces (Proc. VII Taniguchi Symposium), ed. A. Yoshimori and M. Tsukada (Springer-Verlag, Berlin, 1985),

14) A. Blandin, A. Nourtier and D. W. Hone: J. Physique 37, 369 (1976).

15) D.M. Newns: Dynamical Processes and Ordering on Solid Surfaces (Proc. VII Taniguchi Symposium), ed. A. Yoshimori and M. Tsukada (Springer-Verlag, Berlin, 1985).

16) P. W. Anderson: Phys. Rev. 124, 41 (1961).

17) D. M. Newns: Phys. Rev. 178, 1123 (1969).

18) P. B. Wiegmann and A.M. Tsvelick: J. Phys. C : Solid State Phys. 14, 1463 (1981).

19) A. Okiji and N. Kawakami : J. Appl. Phys. 55, 1931 (1984).

20) A. Okiji and N. Kawakami: Dynamical Processes and Ordering on Solid Surfaces (Proc. VII Taniguchi Symposium), ed. A. Yoshimori and M. Tsukada (Springer-Verlag, Berlin, 1985).

21) R. Brako and D. M. Newns: Surf. Sci. 108, 253 (1981).

22) L. V. Keldysh: Sov. Phys. -JETP 20, 1018 (1965).

23) A. A. Abrikosov, L. P. Gor'kov and I. E. Dzyaloshinskii : Method of Quantum Field Theory in Statistical Physics (Prentice-Hall Inc., Englewood Cliffs).

24) K. Makoshi, H. Kawai and A. Yoshimori : J. Phys. Soc. Jpn 53, 2441 (1984).

25) A. Yoshimori, K. Makoshi and H. Kawai : Dynamical Processes and Ordering on Solid Surfaces (Proc. VII Taniguchi Symposium), ed. A. Yoshimori and M. Tsukada (SpringerVerlag, Berlin, 1985). 
26) A. Yoshimori, H. Kawai and K. Makoshi : to be published in Prog. Theor. Phys.

27) N. D. Lang : Phys. Rev. B27, 2019 (1983).

28) N. D. Lang and J. K. N $\phi$ rskov : Physica Scripta T6, 15 (1983).

29) N. D. Lang: Dynamical Processes and Ordering on Solid Surfaces (Proc. VII Taniguchi Symposium), ed. A. Yoshimori and M. Tsukada (Springer-Verlag, Berlin, 1985).

30) A. Nourtier: Thèse d'État, Orsay (1976).

31) J. N. M. van Wunnik, R. Brako, K. Makoshi and D. M. Newns : Surf. Sci. 126, 618 (1983).

32) J. N. M. van Wunnik: Thesis, University of Amsterdam (1982).

33) J. N. M. van Wunnik, J.C. C. Geerlings and J. Los : Surf. Sci. 131, 1 (1983).
34) P. Nozières and C. T. de Dominicis : Phys. Rev. 178, 1097 (1969).

35) N. I. Muskhelishvili : Singular Integral Equations, ed. J. R. M. Radok (P. Noordhoff N. V., Gronigen 1953).

36) P.W. Anderson: Phys. Rev. Lett. 18, 1049 (1967).

37) A. Nourtier: J. Physique 38, 479 (1977).

38) A. Yoshimori and J-L. Motchane: J. Phys. Soc. Jpn 51, 1826 (1982).

39) J. E. Inglesfield: Surf. Sci. 127, 555 (1983).

40) J. Roussel : Physica Scripta T4, 96 (1983).

41) K. Makoshi and D. M. Newns : preprint.

42) Z. Šroubek, K. Zdansky and J. Zavadil: Phys. Rev. Lett. 45, 580 (1980).

43) K. G. Wilson : Rev. Mod. Phys. 47, 773 (1975). 